\title{
Land: Israel, Place, and Presence
}

It's a miracle that Israel is a nation again. It's a miracle Hebrew is spoken again when it was a dead language. It's a miracle that all these people from the rest of the world is coming back to this land; [but] it's also an everyday, normal regular city, country in the world, it's like everywhere else in the world, but at the same time it's like nowhere else in the world. So that makes it unique. And even though I feel like this is the place God wants me to be so far, I don't know if one day He says, 'No', well then I'll go wherever He wants me to go. But so far I think this is my home.

JENNIFER, 2013

The coming-to-Israel narratives that were analyzed in the previous chapter described how God had called the volunteers into service in Israel, thereby framing the motivation for being in Israel as miraculous in nature. Although similar stories likely would be found among Evangelicals engaged in shortterm mission, or volunteer work in other geographical locales (e.g. Hancock 2013, Howell and Dorr 2007), Israel, for the volunteers, is a country unlike any other. For them, Israel is "the land of the Bible": a place of miracle and wonder, and a place of "spiritual intensity" (and sometimes equally intense danger). In short, Israel is a place where God's presence is most tangibly and acutely felt. This ontological uniqueness of Israel, which is derived from its expected role in God's redemptive purposes, leaves the country shimmering with an otherworldly light. But at the same time, the volunteers often insist that Israel is a country like any other: a place where people go to work in the morning and home in the evening; where groceries and housing are far too expensive; where there is secularism, sin, poverty, violence, pollution, and general ungodliness. Israel is simultaneously of God, and of the World.

The task of rightly locating Israel spiritually invites the volunteers to negotiate the relationship between place and divine presence, a relationship which has often been contested within Protestant history, and which theologies at the liberal end of the spectrum have often understood in terms of fetishism. 
For some volunteers this negotiation creates theological problems: how is it possible to confess dedication to the Evangelical credo that God is immediately accessible everywhere (Luhrmann 2004), and at the same time the deeply felt experience that God is most particularly available in Israel? Where does the boundary go between Israel as a sort of territorial prelude to the millennial kingdom on the one hand, and Israel as an ordinary country on the other?

This chapter explores the volunteers' narrative constructions of Israel as a sacred space and places these discourses in relation to academic conversations about place, presence, and mediation (Engelke 2007, 2010a, b, Keane 2009, Smith 1987, 1993, Stolow 2005). In the first part, the discourses of the volunteers are discussed in light of Jonathan Z. Smith's theory about religion and place, and it is argued that their narratives about Israel provide examples of what Smith has called a "locative" religious orientation, which is rather conspicuous given Evangelical Christianity's more general "utopian" orientation. As locative religiosities connect place to divine presence, the second part of the chapter relates these discourses to what has been called "the problem of presence", namely, "the problem of ... how a religious subject defines and claims to construct a relationship with the divine through the investment of authority and meaning in certain words, actions and objects" (Engelke 2007, 9). Here I suggest that the problem of presence emerges particularly in relation to Israel, not as the place where the biblical events played out historically, but rather as the "land of the restoration". Finally I turn to the question of how the tensions that are created both by the religious significance attributed to Israel and the empirical experience of the place are negotiated in the discourses. Before we turn to these problems, however, a more general introduction to the place of Israel in Christian imaginaries will be necessary.

\section{Space, Place, and the "Holy Land"}

The "Holy Land" as understood in Christian and Jewish imaginaries can be seen as a paradigmatic example of a sacred space. According to historian of religion, Jonathan Z. Smith, a sacred space

... is a place of clarification (a focusing lens) where men and gods are held to be transparent to one another... The ordinary (which remains, to the observer's eye, wholly ordinary) becomes significant, becomes sacred, simply by being there. It becomes sacred by having our attention directed to it in a special way. That is, there is nothing that is inherently sacred or profane. These are not substantive categories, but rather situational or relational 
categories, mobile boundaries which shift according to the map being employed. There is nothing that is sacred in itself, only sacred things in relation. SMITH 1982, 54-55 emphasis in original

In contrast to - but also in the same tradition as-Mircea Eliade's understanding of the sacred and the profane, Smith views these as constructed categories that are dependent on different cultural factors such as inherited narratives, texts, religious practices, and culturally determined ways of seeing. Sacred spaces in Smith's view, are made, not found. ${ }^{1}$

Historically, the land of Israel, and Jerusalem in particular, has held a central place in the religious imagination of Jews and Christians as well as many other religious communities. In biblical history, the identification between Jerusalem and divine presence goes back at least to the Zion theology that pre-dates the exilic period (587-539 вСЕ), but it is difficult to establish the exact origin of this tradition with any certainty (Smith 1987, 48). The ancient Zion traditions identified the mountain in Jerusalem as a place of particular sacred significance; this was the place that YHWH had chosen to dwell, the place where a temple was to be built and cults organized (Friis 1996). The exilic/post-exilic sections of the Hebrew Bible (most particularly Ezekiel 40-48) offer what Jonathan Z. Smith has called an "ideology of place" (Smith 1987, 48), an imaginary map of an ideal cultic place centered on Jerusalem and on the temple. But the ideology of place stretches beyond the temple cult alone: "In a sense" Smith writes in Map is not Territory,

the entire Old Testament, may be understood as a complex creation myth concerning the establishment of the land in which a man can be truly human and at home. In Israelitic terms, it is a myth of the establishment of Israel the land and the people of Israel.

SMITH 1993, 110

This ideology of place, of course, is embodied in many of the texts that Christianity later inherited from ancient Israelite and Jewish religion. However, in his "Christian Ideology and the Image of a Holy Land" (1991b, a), ${ }^{2}$ the anthropologist

1 For Smith's discussion of Eliade see his "The Wobbling Pivot" (1993, 88-103).

2 Bowman's article "Christian Ideology and the Image of a Holy Land: the Place of Jerusalem Pilgrimage in the Various Christianities" exists in different versions under the same title. In the following I am referring to the longer (44p) version that is available on: https://www .academia.edu/265156/Christian_Ideology_and_the_Image_of_a_Holy_Land (accessed 2019 -o6-25). A shorter version (24p) of the same article is available in Eade \& Sallnow's Contesting 
Glenn Bowman describes how early Christianity gradually developed a new "textual" understanding of place. This "textualization" of "the Holy Land" was "an integral part of the process by which Christianity was transformed from a dissident sect within Palestinian Judaism to a universal religion embraced by peoples throughout the world" (1991b, 2). By "textualization" Bowman refers to a process in which the actual place gradually became eclipsed by the Israel of Christian imagination as it appeared in Bible readings, stories, hymns, and liturgies. Bowman does not here refer to Smith; if he had, he would perhaps have recognized this textualization process as a transition from a "locative" to an "utopian" religious orientation, a process which Smith describes as not limited to the so-called "parting of the ways" between Judaism and Christianity but as a much broader development among ancient religions in the first centuries CE (Smith 1987, 1993). For Smith, the terms "locative" and "utopian" serve to distinguish between different religious orientations or symbolic systems. While the "locative" vision of the world emphasizes place and order and has a cult centered around purity, the "utopian" vision by contrast highlights the "value of being in no place", rituals of transformation, and the imperative that the religious practitioner transcends the world. For Smith, the transition to a utopian religious mode in antiquity is connected to diasporization:

For the native religionist, homeplace, the place to which one belongs, was the central religious category. Ones [sic] self-definition, ones [sic] reality was the place into which one had been born — understood as both geographical and social place. To the new immigrant in the diaspora, nostalgia for homeplace and cultic substitutes for the old, sacred center were central religious values. For the thoroughly diasporic member, who may not have belonged to the deity's original ethnic group, freedom from place became the central category. Projecting the group's diasporic existence into the cosmos, he discovered himself to be in exile from his true home (a world beyond this world), he found his fulfillment in serving the god beyond the god of this world and true freedom in stripping of his body which belonged to this world and in awakening that aspect of himself which was from the Beyond.

SMITH 1993, xiv, emphases in original

the Sacred: The Anthropology of Christian Pilgrimage. London: Routledge, 1991 (reprinted later by Illinois University Press 2000 \& Wipf and Stock 2013). However, in the shorter versions much of the historical discussion that interests me here is missing. I have confirmed this information, and discussed my usage of the text with Bowman in personal correspondence 2015-08-04. 
Diasporic, in contrast to locative religion was utopian, "a religion of nowhere" (Smith 1993, xiv), or of "anywhere" as Smith has written elsewhere (2004). "Uprooted" socially and perhaps geographically from the previous center, utopian religion came to value that which previously had been a defect: homelessness and detachment from place. The true home could no longer be found in this world, it could only be found within, or beyond, so religious practices began to shift mode from an emphasis on the purity of place to the transformation of self. God could only be found beyond this world or through the transformation of the self, not in particular geographical places. The "textualization" of early Christian imaginaries of the "Holy Land" that Bowman describes, then, should be seen as a part of a broader process leading towards more utopian orientations in ancient religion. Although the biblical names and places continued to be remembered in liturgy, hymns, and narratives, they had little connection to the concrete geographical places in the Roman province Syria Palaestina. What mattered most to these early Christians was heavenly Jerusalem, not Aelio Capitolina (1991b, 13).

In spite of the transition from locative to utopian religious orientations that took place in antiquity — and of which the early development of Christianity was a part-it is important to note that these terms should neither be understood as evolutionary, nor should they be seen as mutually exclusive.

[B]oth have been and remain coeval existential possibilities which may be appropriated whenever and wherever they correspond to man's experience of his world. While in this culture ... one or the other may appear the more dominant, this does not affect the postulation of the basic availability of both at any time, in any place.

SMITH 1993, 101

Furthermore, I do not mean to claim that the development from a religiosity focused on place, to a "religion of nowhere" was anywhere near as linear-or indeed as complete-as it might appear in this brief overview. Christian imaginaries have taken many different directions with regards to place throughout history and continue to do so today (Coleman 2000a, Tweed 2000, Westergren 2012). In fact, a central part of my argument here is that the Christian Scripturesand consequently also Christian history and tradition - contain both of these orientations simultaneously. ${ }^{3}$ How these are understood depends on interpretative standards as well as theological, ideological, and cultural preferences.

3 The biblical scholar Pamela Eisenbaum, for instance, has analyzed the Letter to the Hebrews through Smith's terminology. Understood as such, the supersessionism of which Hebrews is 
Evangelicals, like other Christians, have a reservoir of biblical stories to draw on when making sense of their encounter with the land, as well as when trying to understand the role of Israel in salvation history. This narrative reservoir, as we shall see, creates both interpretative possibilities and theological tensions.

\section{The "Land of the Bible" and the Evangelical Gaze}

"The American Protestant gaze on the Holy Land", Feldman and Ron write, "has been influenced, not only by biblical paradigms, but by Orientalist worldviews and the process of theming and disneyization" $(2011,151)$ and, they stress, "like all ways of seeing, is not natural, but is historically, socially and ideologically conditioned" $(2011,169){ }^{4}$ This constructivist perspective, although I believe it accurate, would not be shared by the volunteers in Jerusalem. For them, their gaze on Israel is perhaps not "natural" but it is "biblical", and as such, unconditioned by subjective, ideological, and historical processes. The Israel that they see demonstrates two essential and unchanging characteristics: it is "the land of the Bible" and, as a consequence of this special status, it is marked by a fundamental alterity. For Adam, the uniqueness of Israel is framed as the main reason he came to work in Jerusalem.

One of the reasons I wanted to come to Israel was of course, my main reason was to, I mean ... this is the land of God. There's no doubt this is where it all happened. This is where Jesus walked, where He talked, where He did His miracles. Galilee, you know, up there, what happened there, where the great miracles he performed, he walked on the water. I wanted to see all those things, I wanted to be in the land of Jesus; I wanted to walk in His footsteps. I love Jesus and I wanted to get to know Him as much as possible, not just through the Bible. Of course you don't have to come to the land, but if you come here you get a visualization of everything much better-you understand what I'm saying?

As also observed by other authors who have studied Christian pilgrims in Israel (Feldman 2016, Kaell 2014), this is often phrased as an experience that "brings the Bible to life", or that makes a previously two-dimensional text assume a third dimension.

often criticized is better described as a theological argument for a utopian religious orientation (Eisenbaum 2013).

4 Jackie Feldman in particular has written several accounts of the narrative construction of Israel in tour guide performances, by different agents in the land, and by the travelers visiting there (see: Feldman 2007, 2011, 2013, 2016). 
To be able to be in the place where it's happened, it's brought life to sometimes the two-dimensional words that we read on a page. Kind of those letters get raised up and things start getting put into perspective. So I think volunteering in Israel is a great way to increase your faith and to actually see the places. When I drive along the highway and I'm: " $O h$, there's Nazareth." [chuckles] "Oh, I've heard about that once or twice before!" It kind of brings some understanding about who Yeshua was. And so, yeah, definitely a deepening of my walk with God; [my faith] has definitely been deeper since, you know, realizing Israel.

In the excerpt Ron also connects his encounter with the land to his previous experience of "realizing Israel" which in the previous chapter was discussed in terms of a continuous conversion: realizing contemporary Israel's spiritual significance and being able to live in the land has "definitely" deepened his "walk with God".

"The land of the Bible" is a narrative construct with which most Christians have, to some extent, been familiar most of their lives, but also something that travelers to Israel encounter in tour guide narratives and the products of the tourism industry, albeit in different ways that depend on their denominational and cultural backgrounds (Bajc 2007, Feldman 2007, Goldman 2009, 10-14, Kaell 2014). Generally speaking, "the land of the Bible" refers to the significance of the land in biblical history and the geography's connection to the biblical narratives. The places where it is believed that the biblical events occurred naturally play a significant role in this construct, but so do more modern additions, such as Yardenit, the Jesus Boat, and the Garden Tomb, where authenticity does not rely on historical or archeological evidence but rather on association and familiarity (Kaell 2014, Shapiro 2008). ${ }^{5}$ Contrary to many travelers' expectations, such a narrative production is not ideologically neutral but can instead be-and often is-employed in the service of the interests of the

5 Yardenit is a baptismal site by the Jordan River that was developed by the Israeli government in the 1980s: "this well-equipped site is not linked with any church or mentioned specifically in any scriptural or traditional source. Yet it has become, over the course of 25 years, the place of immersion for almost all American Christian [pilgrims]" (Feldman and Ron 2011, 159 emphasis in original). The Garden tomb is run by a UK based ministry and has over the years developed into a Protestant alternative to the Holy Sepulchre (Kaell 2014, 78-80). "The Jesus Boat", finally, was found in 1986 by two Israeli fishermen and is now displayed in Yigal Alon Museum. "The discovery [of the boat]", Kaell writes, "helped speed the creation of a sophisticated 'worship boat' industry" (Kaell 2014, 82). All three cases exemplify how it is possible to produce and maintain an image of Israel as the Bible land even in sites lacking any serious claims to historical or archeological authenticity. 
conflicting parties (Feldman 2011), or to gloss over political contestation (Feldman 2007). "During biblical tours", Feldman argues, "Jewish Israeli guides and Protestant pastors become coproducers of a mutually satisfying performance that transforms the often-contested terrain of Israel-Palestine into Bible Land" (Feldman 2007, 351).

However, while the "land of the Bible" is a generic narrative theme that is used both by tour guides and travelers, it does not necessarily signify the same things or evoke the same connotations or sentiments across the denominational spectrum. For many Evangelicals - and certainly for the Evangelicals discussed below- "the land of the Bible" is not limited to representing the connections between biblical history and the land. In fact, several of them consider these connections of less personal religious significance than the relationship between the Bible and present-day Israel. To exemplify this: in an interview with an older couple, Tom and Susan, who have been volunteering in Israel on and off for the past twenty years, Tom explained to me that what made the greatest impression on them the first time they came to Israel was not the biblical past but their encounters with the modern history of Israel:

Because what we saw was what God is doing in this country with His people now - not necessarily what happened a long time ago in the Bible. Now we did see the Bible places, but what impacted us I think more than anything was that God is doing something even now in this land with this people: the fact that they are returning, the fact that the land is blooming again and all of that.

For this American couple, the most significant part of their first trip to Israel was not to see the biblical places, to "walk where Jesus walked" (Kaell 2014), but rather to have first-hand experience of "the restoration". It was not the biblical past that caught their attention, but the "biblical" present: what God is doing in the land now. The religious significance of the modern places and events is found in the fact that they are more able than their historical counterparts to demonstrate God's continuing activity in the world. This is not an isolated case. Several scholars have observed how Evangelical Zionists invest religious authority and meaning in modern and seemingly secular places in Israel such as the Knesset, Independence Hall, the military cemetery on Har Herzl, and social institutions such as immigration centers. (Shapiro 2008, Belhassen 2009, see also: Engberg 2016). Visiting these sites while listening to the tour guide narrations that frame them as monuments to the return of the Jewish people to their land enables an Evangelical audience to witness the restoration first 
hand, and in consequence, God's continuing redemptive action in the world. Israel's narrative identity as the trans-historical land of the Bible is significant in this context because it explains how seeing a country experience socioeconomic growth, immigration, and the modernization of agricultural forms (or watching the "desert bloom" in Christian Zionist vernacular) can be cognized as signs of what God is doing in the land now.

As the development of contemporary Israel is generally understood among the volunteers to have been foretold in the Bible, modern developments too can be understood as "biblical" events. And as the expected future of Israel is of crucial significance in God's redemptive purposes the same applies here. As a result of being embedded in salvation history, all of which is recorded - sometimes opaquely, sometimes transparently —in the Scripture, the "land of the Bible" represents a hermeneutical node point, a "fixation" (Durbin 2013b, see also: Johnson 2000) that connects Israel's biblical past with its equally "biblical" present and future. In this sense, for many Evangelicals, the land of the Bible is a trans-historical construct that makes manifest the symbiotic relationship between the land on the one hand and the Bible on the other. In a similar way as previously nonsensical or boring passages in the Bible can acquire new meaning when one has walked the land, seen the biblical places, felt the burning sun, and touched the stones (Kaell 2014, 166), an object - the State of Israel - previously without or with limited (spiritual) meaning can become spiritually significant due to its embeddedness in biblical narratives. Through this process of "biblicalization" (Harding 2000, 194) biblical authority and spiritual meaning is transferred from the biblical text to the State of Israel.

The alterity of Israel-in this case, both the land and the people-is derived from the biblical narratives where the people is chosen and the land is promised, as well as the locative passages where Jerusalem is described as a cosmological center. While the land is repeatedly referred to as "special", "different", and "unique" in the interviews, the Jewish people is also animated by a biblical imagination that defines a sharp distinction between Jews and others. Tommy, for instance, describes in an interview how there are two different peoples in the world: "Jews and Gentiles", and criticizes those who make further distinctions. The "biblical view", he says, is that you are "born either a Jew or you're born not aJew". For Tommy, the distinction between Jews and Gentiles is not merely a question of ethnicity, culture, or religion; it is a fundamental, cosmological distinction that transcends social construction. For him, as for other volunteers, this separate status of the Jews is generally understood positively: the Jews have been chosen by God for a special destiny. But more than being a normative claim and a positive evaluation, it is often phrased just as a simple factual statement. This fundamental alterity of the Jewish people is 
what historian Paul Boyer has called a "cosmic otherness" (Boyer 1992, 220), and the sociologist Zygmunt Bauman in another context has referred to as "allosemitism" (Bauman 1998, 2009). ${ }^{6}$ Allosemitism is a term that was coined by the Polish literary historian Artur Sandauer, but the sense in which I employ the term here is developed primarily by Bauman. It refers to

... the Gentile practice of setting the Jews apart from all the rest as people radically different from all and any other people and therefore needing separate concepts in order to be described and comprehended, as well as special treatment in all or most social and cultural situations. ... "Allosemitism" is an intrinsically ambivalent attitude, able to embrace everything from love and respect to outright condemnation and genocidal hatred, and so it faithfully reflects the endemically ambivalent phenomenon of "the other", the stranger - and, consequently, of the Jew who, in Europe at least, is the most radical incarnation, indeed the epitome, of the stranger.

BAUMAN 2009

In my view, "allosemitism" more accurately captures certain Evangelical understandings of Jews and Jewishness than the more common labels "antiSemitism" and "philo-Semitism", primarily because allosemitism does not carry the same normative burden and as a consequence of this functions better analytically. In the interviews both Israel as a land and the Jews as a people are repeatedly described as fundamentally different from anything and anyone else in a way that has no correlation to particular Jewish customs or habits, social organization, or culture. Their difference is of a different nature altogether: it is spiritual, even cosmological. They are different because God wanted to make them different, and they will remain so until their purpose is fulfilled.

The fundamental alterity of "the land of the Bible" as it emerges when structured by the Evangelical gaze partakes in the narrative construction of Israel as a sacred space. If such a space, as Smith suggests, is something that it is made, rather than found, and if it becomes sacred "by having our attention directed to it in a special way" $(1982,55)$, it might be useful to explore how attention is directed towards Israel. In the interviews this happens in several different ways, primarily by interpreting Israel as being a result of divine agency, and by constructing connections between contemporary Israel and the biblical

6 "Allosemitism" comes from the Latin term for the other: allus. For Bauman, allosemitism is the root phenomenon of both anti-Semitism and philo-Semitism. 
text. What emerges in these discourses is an Israel where a particularly potent presence of the divine resides, and as a consequence, a new formulation of a locative religious symbol system.

\section{Where Miracles Happen}

In many of the stories about Israel miracles play a significant role. Jennifer, who provides the introductory quote to this chapter, gives voice to some frequently occurring ideas when describing Israel and events in Israeli history as miraculous. The birth of the nation, the revival of Hebrew as an everyday spoken language, socio-cultural developments, Jewish immigration, the "discovery" of (some of) the lost tribes, ${ }^{7}$ economic growth, the modernization of agricultural forms, and scientific advancements and discoveries are all areas that are commonly considered spectacular enough to classify them as "miraculous".

I don't think man could have come up with a plan like this. I really don't. I think we're too stupid. We can't even feed the hungry in the world, much less put together a nation like this. This was a supernatural event. And I think if somebody has a problem with it they need to take their argument to God. ${ }^{8}$

The practice of narrating miracles often relies on the ability to frame an historical event as a marvel, as something worthy of special admiration, as something so spectacular that explaining it in other terms than as a miracle seems

7 The "lost tribes" refers to the idea that ten tribes of the twelve that purportedly constituted the Jewish people were lost when the Assyrians captured the northern kingdom and deported its population in 720 BCE. The scriptural basis for this idea comes primarily from 2 Kings 17:6. Today there is growing enthusiasm for the quest to find those lost tribes of the Jewish people, amongst both Christian Zionists and some Jewish organizations (for instance: Shavei Israel). The two most famous examples of lost tribes that have been "found" are the Bnei Menashe of northeastern India and the Falashas of Ethiopia, both of whom have been granted the right of immigration to Israel under the law of return. Apart from those two, there are numerous other ethnic groups around the world who are, or have been, claiming descent from the lost tribes, such as the Igbo of Nigeria, the Lemba of South Africa, the Bnei Anousim of Spain and Brazil, and the Pashtuns of Afghanistan and Pakistan. Methods of proving descent from the lost tribes include anthropological observations, examinations of history and religious customs, and DNA testing. The whole endeavor however, is deeply embedded in ideological discourses and tends to essentialize ethnic and racial characteristics, which often makes the project appear problematic from an historical scholarly point of view. For research about these practices see, for instance, (Egorova 2015, Erasmus 2013, Kaplan 2006, Parfitt and Egorova 2005, Tamarkin 2014).

8 Jacob 2012. 
to capture less than the whole picture. Jacob, for instance, frames the state of Israel as a miracle precisely because he believes human nature incapable of creating something so great. "A nation like this" is meant to capture the splendor of the Israeli state. Expressions of admiration for Israel are indeed very frequent in interviews and emphasis is generally placed on all the things the Israelis are felt to excel in politically, scientifically, and morally. In publications from the ministries, as well as in interviews with the volunteers, Israeli scientific breakthroughs are often reported as particularly admirable, and as cases of Israel's "blessing the world".

That events are framed as miraculous, however, are, as Andrew Singleton has argued, also the result of particular rhetorical strategies, such as the privileging of certain cultural meanings at the expense of others (2001, 121). In similarity to the calling narratives that were analyzed in the previous chapter, narrative non-sense making here serves such a rhetorical role in situating events as miraculous and consequently directing our attention to a particular framing that embeds Israel in the sacred. 9 "You can't explain things like that"; $; 0$ and, "Now, you can't make this stuff up",11 are common rhetorical markers that serve to emphasize the supernatural origin of the events told. By de-emphasizing natural causes and alternative causalities the remaining option is that the birth of the nation, or a particular socio-political development, is the result of divine agency. Much as narrated miracles sometimes serve a rhetorical role in the construction of religious conversions (Stromberg 1993, 76-100), and as a source of spiritual authority (Shipley 2009), these stories are mobilized to bolster Israel's authenticity as a sacred space. Narrated miracles direct attention in that "special way" (Smith 1982, 55).

9 For a discussion about the relationship between miracle and magic and the epistemological and ontological connotations these carry in anthropology, see (Shanafelt 2004). Shanafelt suggests "marvels" as an alternative to these terms as it has more "cross-cultural utility ... without the implied hierarchy of monotheism or traditional anthropology" (Shanafelt 2004, 322). I use miracle here as it is the emic term most commonly used by the volunteers, but I do not mean to imply that miracles, understood as expressions of supernatural agency that somehow subvert the "natural" order of things are in any way qualitatively different from other such expressions of agency such as magic or other supernatural phenomena. What is a miracle is highly dependent on culturally transmitted understandings of the "natural" (Keane 2009), and hence discussions about miracles make most sense when discussed in relation to the cultural context within which they are encountered.

$10 \quad$ Philip and Nancy 2013.

$11 \quad$ Philip and Nancy 2013. 
However, supernatural involvement is not limited to Israeli history and Jewish life in Israel in general. Many of the volunteers refer to miracles that have happened to them personally in Israel, and some argue that it is a fact that miracles takes place more frequently there than anywhere else. These events too are often narrated as arguments supporting Israel's positioning as a place of divine presence. Adam, for instance, describes how during his first time in Israel, a period in which he did not have an income, he continuously "found money on the road".

Every day I found money so I could buy my, I could buy rice, I could buy bread, I could buy this or that. Every day! And every time when I found money I did as the Bible says, I took $10 \%$ of it and I gave it to some poor people. And the money multiplied. I have no idea [how]. Today I cannot explain.

Another volunteer describes how he was cured of a pre-cancerous "thing" on his face and, in another instance, how he was involved in praying for a Jewish couple who were unable to have children. The result of this intercession was that the woman called him two weeks later and told him that she was pregnant. ${ }^{12}$ These are just two of "miracles upon miracles upon miracles" that he could tell me, he says. All of these have happened to him during the last seven to eight years that he has spent in Israel.

Of course, it is hardly surprising that Evangelicals refer to miraculous events, acts of God, or intense religious experience in their personal life stories. As Tanya Luhrmann has shown (2012), "supernatural" experiences might be far more common than we have previously thought, and charismatic Evangelicals and Pentecostals are probably more inclined than most other Christians to embed this type of experience in life stories. Belief in a personal God that is actively involved in the lives of believers is part of the core dogma of Evangelical faith. The interesting detail here, however, is how personal miracles and religious experiences are discursively linked to the place in which they are narrated as having occurred.

Agnes is a middle-aged American woman for whom the realization of the spiritual significance of Israel came late in life. She grew up in the mainstream of the American church landscape and consequently had prior knowledge of the biblical texts about Israel yet "had never really understood" she says. When she took a tour to Israel as part of a para-church organization with 
which she is involved, insight about Israel came to her through an intense emotional experience.

The one experience with the most impact was when we came into Jerusalem ... At least it's been my experience [that the tour guide organizers] try and bring you in, you know, when the sun is setting and it's gold and pink and beautiful and we got to the hotel and we went to dinner. And my friend who was, who came with me, we were sitting in a table; I don't think we even ate that night. It was like we just could feel the presence of God almost like a shower you know. And I'm not the kind of person that normally experiences God in that way. I'm pretty logical, pretty analytical, pretty ... show me the facts, you know. If I can touch it, feel it; I'll believe it .... And this was totally different. And so we sat at that table and Mary said to me, she said, "We need to pray big prayers. There's nothing too big to pray." And so we just started praying and, like I said, the next thing we knew we looked around and there was nobody in the room, everybody had finished dinner and had gone and we were just oblivious, you know. There was just nothing except God and it was like a download almost. (my emphasis)

Agnes tells this story about her religious experience in an attempt to explain the point at which she realized the spiritual significance of Israel, a realization that is discursively connected to the encounter with Jerusalem, which in her story becomes an encounter with God. ${ }^{13}$ When sitting in the restaurant, and watching the sun set over Jerusalem's rooftops she could "feel the presence of God almost like a shower", and she describes how she (and her friend) even lose track of time. ${ }^{14}$ The potency of their religious experience as it comes to them mediated through Jerusalem, was "like a download almost" which made them oblivious to their surroundings and the passing of time. Agnes never says that this experience could not have taken place somewhere else, Jerusalem is not framed as a pre-condition to meeting God; nevertheless, place is of relevance here. It is relevant both because Agnes situates the experience within

13 See Feldman (2016) for a tour guide perspective of pilgrims' encounters with Jerusalem.

14 Luhrmann has described how this type of religious experience is more common among people who score high on Tellegen's absorption scale which correlates with the vividness and richness of inner mental worlds, susceptibility to hypnosis, and "the ability to take pleasure in music, literature and the arts" (2012, 199). Tellegen's scale is understood to indicate one's relative ability to become so absorbed in something that it engages one's mental resources completely. 
the geographical context of Jerusalem - the hotel and the beauty of the roofs at sundown - but even more so because the very rationale for telling the story in the first place is not the religious experience as such but to explain how she realized that Israel as a place was of significance to God. This realization came to her not through reading the Bible, nor listening to pastors, but through the theophany that she experiences in the encounter with place: through the intense feeling of the presence of God streaming down on her, almost like a shower, or a download.

The religious experience that Agnes had in Jerusalem is not a coincidence. Several volunteers describe how a particular presence hovers over Jerusalem emanating a spiritual intensity which is simultaneously cherished and challenging. Below, I will use this example to discuss another way in which Israel is discursively produced as a sacred space: the construction of links between place and the biblical text.

\section{"God's Fire Is in Zion, but His Furnace Is in Jerusalem"}

In many interviews with the volunteers, a personal calling is not only described as a personal motivation or as a way to express dedication to one's chosen path but also as a spiritual prerequisite for service in this particular place in the world: "you have to be called to do it really, you know", one American woman explains to me. Unless you are called "you may get it here", her husband continues while he pats his head, "but not here", he says, pointing to his heart. ${ }^{15}$

The requirement of a calling might at times refer to the dedication and tenacity needed to travel across the world, to live in a foreign culture, and to do voluntary work, all of which is probably easier with a conviction that the journey is not entirely a matter of choice but rather an expression of the will of God. Sometimes, however, the calling requirement has additional connotations that have more to do with what is needed in order to function spiritually in this specific, and peculiar, place. In these discourses, Israel, and Jerusalem in particular, is described as "spiritually intense"16 and as such it is also spiritually challenging and potentially dangerous. Not having a calling in such a place is a risky business because of the spiritual struggles that you will have to face. Jacob, who we met in the previous chapter, reflects on the spiritual danger of Jerusalem.

\footnotetext{
15 Philip \& Nancy 2013.

16 Jacob 2012, Mary 2013.
} 
I don't want to be here any longer than I'm supposed to be here because it's a very dangerous place, and I don't mean physically, I mean spiritually. This place will eat you alive. It will tear you up spiritually if you're not supposed to be here.

For Jacob, as well as for many other volunteers, the danger of Jerusalem is not directly related to any fear of political violence, anti-missionary activities, or even terrorism, at least not explicitly. Such concerns surface in some interviews but they are usually placed in a religious framework; it is a question of faith and it is a question of learning to trust that God will protect you from harm. Often danger is also understood as something that comes with the calling to bless the Jewish people. For Jacob the danger of Jerusalem is not understood as political but rather as spiritual in nature. The intensity is something "almost tangible"; it is something that you can "feel ... in the air", he says. In illustration of this point he refers to several of his Israeli friends who do not live in Jerusalem but who claim to start feeling "the pressure" when they drive up to the city: "They're not born again believers and they feel the tension in the air," he says. When asked to describe the spiritual tension that he experiences in Jerusalem and how he understands it, he begins by drawing on Isaiah.

It says in Isaiah, you know, "God's fire is in Zion but His furnace is in Jerusalem." And His furnace is here in Jerusalem. And you feel that furnace. The heat gets turned up in your life and things that you never thought you had a problem with, all of a sudden you're like, "Wow, I didn't know that was in my personality," you know. And the Lord always knew it was there. ${ }^{17}$

This description-mirrored in several other interviews but rarely explicated in this way-is in sharp contrast to the stories about the miracle and wonder of the land of the Bible discussed above. And it is delivered with a very different and more severe, even grave, tone. Being exposed to the "furnace" is not a happy-clappy religious high. Feeling that furnace is not even a pleasant experience; it is rather one of being severely challenged, of being out of your depth, of being forced to change.

Jerusalem has a way of finding your Achilles' tendon [sic] and God uses that to expose our weaknesses to Him and then we can do something

17 The Isaiah text that Jacob refers to is found in Isa. 31:9: "His rock shall pass away in terror, and his officers desert the standard in panic', says the Lord, whose fire is in Zion, and whose furnace is in Jerusalem" (my emphasis). 
with it where He can, He can work in our life but if we don't know that it exists, you know, Jerusalem will find your weak spot, it will. So I think that's another reason I'm here, it has changed me.

The reason that Jerusalem has this ability to find your "Achilles' tendon", your weaknesses, according to Jacob, is found in the Bible.

Because God wrote His name here; it says that in the Old Testament: that God wrote His name here in Jerusalem. This is a place, a point of contention in the spiritual realm. And there is a battle that is always going on at high intensity. This is the place where Jesus defeated the enemy. And I think that those spiritual principalities and everything that He defeated, you know, two thousand years ago, those things are still hanging around here and they affect the people that are not born again believers. And [for] those who are born again believers, God uses that testing time or that war time to grow you up. And so it is a different level here, I mean, than it is anywhere else in the world. ... This is where everything culminates in a sense. ... There're a lot better, prettier cities than Jerusalem, but there's something about it, and it's because it says in Psalms that God He neither slumbers nor sleeps, He watches over Israel. So His eye is continually here, not because the Jewish people are great, not because they're better than anybody else-in fact He says just the opposite- but it's because this is where He has chosen to place His name.

The spiritual tension that Jacob sees hovering over Jerusalem illustrates a point which underpins this book: the narratives that we carry with us to a new geographical and cultural context structure our "ways of seeing" (Feldman and Ron 2011, 169) and our experience of the encounter with place. Bowman makes this point succinctly; for him Jerusalem is not so much "a holy city" as it is a "multitude of holy cities"; cities which are structured by the imaginaries that Christians (as well as Jews and Muslims) carry with them on their pilgrimages.

This synchronicity of Jewish, Muslim and Christian holy sites suggests that what makes the city holy to the various groups which "go up" to Jerusalem is not something found in the city but, instead, something brought from the outside and matched up there with monuments to, and markers of sacredness.

BOWMAN 1991a, 98 
For the volunteers, particular locative biblical stories and the eschatological narratives - often constructed on the basis of those stories-provide an interpretative framework through which they make sense of their experience in Israel. The "tension" of Jerusalem, and indeed that of Israel in general, might well be interpreted differently by different people who do not have this particular reservoir of stories to draw from when they encounter the land. In other writing, such as media reports and travelling narratives as well as ethnography, Israel is also often described as an intense-even tenseplace (Ben-Ari and Bilu 1997, Markowitz 2013b). This intensity is understood by Jacob as spiritual in origin and nature. Other travelers, however, might rather understand it as emerging from the political situation and the resulting fears and anxieties this has produced; from the bricolage of different languages, cultures, and religions that animate the city; from the peculiar mixture of "Western" and "Eastern" elements it contains; or even from Jerusalem's ancient historical heritage and architecture. Yet other travelers, of course, might not experience Jerusalem as particularly intense at all. Personally, I can relate to Jacob's experience but for me, as an ethnographer and traveler in Israel, the intensity of the city emerges from all these things, but maybe particularly from the elongated and intractable conflict between Israel, the Palestinians, and large parts of the Arab world. Such extended strife, and the equally lengthy period in the media spotlight, has given rise to a politicization of language (see Chapters One and Two), and an ever present ideological component that structures encounters with strangers and places. Jerusalem is a particular nexus where this conflict comes to a head and the resulting tension can, like Jacob says, indeed be "felt in the air" at times. Yet, for Jacob, this feeling — or a similar one — represents something different than it does for me; it says that God has "put his name on this place", that the "spiritual principalities" that Jesus defeated still "hang" over the city, and that you feel God's "furnace" as you walk through the streets of Jerusalem. In a similar way as my understandings inform my experience of the place, Jacob's understandings inform his; none of our "ways of seeing" has a definite claim on "ontological certainty" (Stromberg 1993, 95).

By drawing on some particular biblical passages, Jacob indeed directs our "attention in a particular way" (Smith 1982, 55) that frames Jerusalem as a sacred space. By having his experience of place filtered through the biblical text the Jerusalem of his narrative appears as a cosmological center where spiritual principalities linger and where God's eye is ever watchful. This is achieved in a number of ways: first, by simply quoting these texts and thereafter creatively employing them in his discourse, Jacob makes an implicit argument for their applicability in his endeavor to make sense of his experience of Jerusalem. This 
perhaps seems to be an obvious point, but if it appears so, it is partly because reading Israel in relation to, or even through the Bible has become naturalized in Western cultures through the textualization process that Bowman describes and narrative constructs such as the "land of the Bible". Even secular media at times utilize biblical metaphors and language in articles about Israel, or the conflict.

Secondly, the passages from which Jacob draws (chronologically in terms of his narrative: Isaiah 31:9; 1 Kings 11:36; 14:21; Ps. 121:4) are texts in which Jerusalem is portrayed as a cosmological center. In Isaiah 31 - as in most texts believed to be written by proto-Isaiah-Jerusalem is an "enclave" or "strategic hamlet" (Smith 1993, 109) in which God's presence on Zion is what protects the Israelites from a dangerous and hostile surrounding (see below). For Jacob, this presence is not so much a protection from dangerous surroundings as it is something that forces you to confront your own weaknesses and flaws, that exposes you to God on "a different level", something that forces you to change. Nevertheless, it is a presence that sets Israel apart from the rest of the world; it is where "everything culminates", he says.

Thirdly, and interestingly, Jacob draws on the metaphor of fire that he finds in Isaiah in order to explain the intensity of Jerusalem and how it has an impact on him. Fire is a potent metaphor. In the Hebrew Bible fire is often identified with God, particularly as an expression of God's wrath and destructive powers (Labahn 2006), but also as a signifier of divine presence as in the case of Moses' theophany by the burning bush in Exodus 3. Fire, however, is also a commonly used metaphor in many Western languages usually signifying intense emotions such as love, lust, and anger. Fire is also associated with both attraction and danger, sometimes simultaneously as in the expression "playing with fire". Drawing on the connotations of attraction/danger, creation/destruction, purity/pain, fire is related to catharsis, the flame that cleanses and purifies, and with a suffering that one needs to go through in order to become clean, or free (Diken 2011). Several of the connotations that fire metaphors carry in the English language, as well as in the Bible, seem to have some bearing on Jacob's interpretation of Jerusalem. He identifies Jerusalem with the intensity of strong emotions, with pain, with danger, and with exposure. In terms of catharsis, Jerusalem is understood as a place that will find your weak spots, expose your flaws, and force you to change. The Jerusalem of his narrative is a locus of personal transformation, but a transformation that comes only through the pain of being forced to confront that within you that you did not even know was there. For Jacob, Jerusalem is a flame that purifies. 
This experience of Jerusalem is mirrored in Hanna's narrative about the place but she locates the origin of the tensions less in biblical passages and more in discourses about "spiritual warfare". In her view, too, being in Jerusalem forces you to change, and it is, she says, a painful experience.

H: Someone once told me that it's like an analogy of a bow and arrow and you're stretching the bow with the arrow. You're stretching the bow to the point where you think it's going to snap and then it keeps stretching and it keeps getting further and further and you think, "Wow! I thought that would snap there and it didn't." And it's like the Lord knows exactly where you would snap and He never lets you go there. But being here is about the stretching; [it] is about the growing. And it's been painful but it's been a great experience.

A: Why is it painful?

H: Well I think when you get stretched it hurts because you don't learn through fluffy clouds and marshmallows, you learn through things going wrong. ... Something that I never understood until I came here (and to an extent I still don't fully understand) that's spiritual warfare. The fact that believing in Messiah is not about all of a sudden everything's sweet and lovely and isn't life great ... There are forces of evil in the world and they don't like you very much because of the fact that you're fighting against them. You want people to be saved; that means they're not going to be in hell where [the forces of evil] would quite like for people to be in. And you're working against it and you're trying to bless God's people. And we know from the way that the world is so against Israel and so antiSemitic and you know that that's not just human beings, there is evil behind that. There is such hatred that goes beyond what you'd think is reasonable or normal in any sense. So when you're here and you're seeking to bless Israel, you're seeking to bless the people that the enemy, being the devil, would quite like to wipe off the face of the earth.

For Hanna, siding with "God's people" exposes you to the threat of evil. "Blessing" the Israelis puts you on the frontline in the battle between those evils and the redemptive plan of God. Being in the vanguard, as it were, is both a challenging, but also a rewarding place to be.

In both Jacob and Hanna's discourses Jerusalem is identified with presence: the presence of God; the presence of the "spiritual principalities"; and perhaps even with the presence of self (as in the part of you that you previously 
did not know was there). For Jacob, this understanding of Jerusalem emerges at least partly from his practice of filtering his reading of the place through biblical texts. In doing so, he creates a perspective, or "directs our attention" to particular phenomena that construct Jerusalem as sacred. If sacredness is a "relational category" as Smith has argued $(1982,55)$, Jerusalem becomes sacred primarily in relation to the biblical text.

\section{The Cosmic Center}

In Map is not Territory (1993) Smith discusses the role of Jerusalem in Jewish thought in terms of Mircea Eliade's category of "sacred space" (e.g. Eliade 1959). The problem that he wants to explore in Chapter Five ("Earth and Gods") is directly related to the founding of the state of Israel.

The repossession of the land of Israel in 1947 and the repossession of the site of the temple in Jerusalem in 1967 have reawakened in an acute way the archaic language of sacred space and have reacquainted the modern Jew with a variety of myths and symbols which he had proudly thought he had forgotten, myths and symbols which he had frequently boasted to others that he never had.

SMITH 1993, 105

This change in historical realities can be described in different terms, Smith writes: as a transition from "exile to return", from "deterritorialization to reterritorialization" $(1993,106)$, but ultimately it implies that "a new world has been encountered, and a new mode of being must be assumed" (ibid., 107). In Smith's interpretation of various biblical and rabbinical sources the land of Israel has been understood in different ways throughout history: in the canon of the Hebrew Bible the primary "structure" of the Holy Land was "one of an enclave, a strategic hamlet walled against the demonic forces of evil and chaos, a land of blessing whose walls and blessing requires constant renewal" (ibid., 112). Later rabbinical literature introduced another structure: "the Holy Land as the Center of space ... the very crucible of creation, the womb of everything, the center and foundation of reality, the place of blessing par excellence" (ibid., 112-113). A third understanding discussed by Smith is the tradition that the land of Israel is the center of time as well as space (ibid., $115 \mathrm{ff}$.). In this tradition the land of Israel, particularly the temple in Jerusalem, serves as a linchpin for history, the very point that keeps the cosmos together.

What is important for my purposes here are the quite striking similarities between these textual traditions about the land as a sacred space and the imaginaries of the land of Israel that surface in the volunteers' narratives. It 
has already been discussed how "the land of the Bible" as a narrative construct serves to connect the biblical past with the eschatological future and the volunteers' own present; how the volunteers describe Israel as an ontologically unique place where miracles happen more frequently than in other locales; how the history of the State of Israel is understood as evidence of God's involvement with the world; how Jerusalem is surrounded by spiritual intensity and danger; and how Israel is discursively constructed as a place where God is especially present and experienced. Due to the frequency with which these themes surface in the interviews, these examples could easily be multiplied.

One of the themes which is connected to the idea of a center, Smith writes, is the notion of "home place" which has influenced much of the geographical literature on place $(1987,28-29)$. The "home" is somewhere of particular significance, of familiarity, a place where one belongs. It is a value laden locus of memory, and of nostalgia, fundamentally different from all other places. We have already seen in the previous chapter how "coming home" was an especially significant trope for the volunteers' descriptions of their encounters with Messianic congregations, so it should not come as a surprise that "coming home" is probably the most frequently used description of the volunteers' encounters with Israel. At least half of the interviewees explicitly refer to Israel as "home". Additionally, many talk of it in terms of familiarity and belonging; several of them describe how they feel "homesick" when they have to leave Israel; and one of the interviewees describes how, on coming to Jerusalem, she felt like "a bride that was being taken home to meet the family. Kind of like the Lord was right there with me, you know."18 As I have already quoted Ruth and Jacob in the previous chapter mentioning these themes I will not repeat them here. What is important for the discussion, however, is the relationship between the metaphor of coming home and ideas about Jerusalem as a cosmological center. While there might be many other explanations for the centrality of the home-coming theme in the volunteers' discoursesexpressions of solidarity, an imagined unity in moral and political values, previous familiarity with biblical names and places, and I do believe all of these are relevant-those about Israel as "home" are also expressions of a religious geography that places Jerusalem in the center of the world. ${ }^{19}$ This

18 Cheryl Hauer 2013. Cheryl Hauer is the International Development Director at the Bridges for Peace.

19 My interpretation here differs slightly from Kaell's in her Walking where Jesus Walked. "Home places" among the pilgrims that she studies are constructed through familiarity, for instance by well-known songs heard in new places, or other cultural artifacts that the pilgrims already know from home (2014, 91-95). Although I do not question that 
geography is similar to medieval "T and $\mathrm{O}$ maps" that only contained three continents: Asia on top, Europe on the bottom left, Africa on the bottom right with Jerusalem placed firmly in the center. Then as now, this map was not so much an attempt to represent the actual geography but to emphasize the relative significance of places and to mirror biblical narratives. The frequently reported characteristic of Christian Zionist discourse whereby developments in other countries are directly causally connected to their political policies towards Israel should be seen in relation to a cosmology that positions Israel (and Jerusalem) in the spiritual center of the world and other countries as satellites (Durbin 2013a, b, Shapiro 2012). Echoing this cosmology, one of the American volunteers, when asked about the potential difference between doing the work that she does in Israel and doing it for some other Evangelical ministry elsewhere in the world says:

I think it begins in Israel. And as a result of doing it right in Israel, then all the other ministries around the world are going to do better. The needs are going to be met better, the supply is going to be more if we do it right here first. So we see it as beginning here. We see the Word of the Lord must go forth from Jerusalem for it to be the most authentic and powerful and from God Himself. And then all the other helps in the world are better benefitted. ${ }^{20}$

The transnational flow of resources, the possibility of functioning ministries around the world, even the authenticity of the Word is directly related to the work the volunteers do in Israel. This understanding does not only place Israel in the center of the cosmos, but also links the fate of the world to Israel through a kind of spiritual causality. Attempting an exegesis of the "counter-intuitive" statement"Thank you Israel, for supporting America" - that was uttered by an unnamed Christian speaker at the Feast of Tabernacles, Faydra L. Shapiro explains that

Israel constitutes the center, an axis mundi around which transnational actors can flow. Support for the sovereign Jewish state of Israel allows members of "the nations" to perform a Christian identity and anticipate God's favor through national security and prosperity in their enactment of standing with God.

SHAPIRO 2O12, 13, emphasis in original

the dynamics that she describes are at work among Christian pilgrims in Israel, in light of the other themes discussed here it is probable that the volunteers are expressing something more than (imagined) cultural familiarity when they are describing Israel as a home. 
On an individual and communal level, the performance of identity is certainly at work here but so is the construction of a cosmology, a map of how the world works independently of how humans relate to it. Without such a cosmology, the identity work that Shapiro describes would not make much sense. In this spiritual map, the rest of the world is dependent upon developments in Jerusalem, and the rest of the world will be judged in accordance with the particularities of its relationships to Israel, and to the Jewish people.

\section{A Locative Thrust}

The crucial importance of place in the volunteers' discourses in many respects corresponds to what Smith has called a "locative" religious orientation (Smith 1993, 100-103). The emphases on Israel as a sacred space of miracle and wonder, as the land of the Bible, as somewhere of particular presence, and as a cosmological center, are all closely related to this particular religious orientation. In other respects, however, their understanding of Israel is not compatible with locative religiosity, particularly when considering the obvious lack of rituals centered on purity, ${ }^{21}$ and the transnational character of late-modern Evangelicalism. Part of the volunteers' emphasis on Israel as a locus of God's revelatory activity comes, I believe, from the general textual reliance on particular locative passages of the Bible in Israel-centered Protestant eschatologies. As Pamela Eisenbaum has pointed out, ancient Israel, like virtually all societies in antiquity, was a locative culture and it produced locative texts (Eisenbaum 2013). In the passages where the people is chosen, where the various covenants between God and the Israelites are arranged, where the land is promised, and where the end of exile is discussed, the land of Israel, Jerusalem in particular, is central in the religious imagination. These texts have a definitive locative character. ${ }^{22}$ For modern Evangelical readers that identify the Israelites with contemporary Israeli Jews, the covenantal promises with the modern-day state,

21 It might be argued that this aspect is fulfilled in some Christian Zionists' enthusiasm for work by the Temple Mount Faithful, the prophetic fascination with a coming third temple, and the numerous attempts to breed a red heifer, reported by Yaakov Ariel (1997), Paul Boyer (1992), Colin Shindler (2000), and Timothy Weber (2004). These perhaps more radical Christian Zionist positions are not very frequently expressed in the interviews, however. Furthermore, as the idea behind these phenomena is that Jews, not Christians, should reinstate the temple cult as it is understood from the Bible, it would be more adequate to label this a "vicarious locative religious orientation" than a locative orientation as such.

22 It should be noted, however, that these biblical passages have often been understood differently in Christian tradition, and have been interpreted in accordance with the development towards utopian religiosity exemplified by the early trajectory of Christianity. 
and the end of exile with the Zionist movement-rather than with the end of the Babylonian exile- the conclusion that God is particularly present in Israel is straightforward; in a sense, from this hermeneutical vantage point, the understanding is implied in the text(s).

Another reason for the locative themes that have surfaced in these interviews that might be worth considering is similar to Smith's understanding, already mentioned, of the change in Jewish thought that followed the establishment of the State of Israel in 1948. As we saw in Chapter Two, Evangelical Christians also "encountered a new world" when the envisioned and hoped-for political construction finally took place following the British withdrawal from the mandate. In spite of the primacy of biblical imagination over concrete place in previous Christian understandings of the "Holy Land" - the "textuality" that Bowman argues for-radically changing historical realities tend to have a significant impact on religious thought. Up until ' 47 , the Jewish state that Christian authors had wished for was a fantasy; in ' 48 it was suddenly historical reality. Now Christian thinkers were confronted with the need to determine if, and to what extent, this new political construct corresponded to the imagined millennial Kingdom. Was Israel the millennial kingdom, was it a precursor of it, or was it rather an unexpected historical development that did not correspond to the expected future? As several authors have shown, in spite of the radical futurism of classic dispensationalism, they rarely settled for the third option (Boyer 1992, Weber 2004). Biblical texts previously drawn upon to argue for eschatological scenarios became texts that were more or less descriptive of a contemporary state. As we saw in Chapter Two, this blurring of the boundaries between the present State of Israel and the millennial kingdom was also visible in the ICEJ's formulation of covenantal theology. An outcome of this process, at least as it seems from the perspective of the volunteers in Jerusalem, may have been a significant surplus of religious meaning. This surplus, applied to the State of Israel, provided it with some of the qualities previously ascribed to the millennial kingdom. For the volunteers, the State of Israel is not identical with the millennial kingdom, but it resembles it, even pre-figures it; for now, being in Israel is as close as it gets to the Kingdom of God.

In Jonathan Z. Smith's terminology, the volunteers' narrations of Israel seem to constitute a clear thrust in a locative direction. This characterization of their discursive practices is not introduced here for mere taxonomical value, however; I have chosen to discuss the discourses in these terms in order to illustrate the theological tensions inherent in the volunteers' understandings of place, presence, and mediation, to which we now turn. For many volunteers, as for Jennifer above, Israel is unique, and it is not; place is important, and it is not; Israel is an especially important locus for the presence of a God that 
is nevertheless believed to be universally available. These paradoxes will be examined in relation to what has been called the "problem of presence" (Engelke 2007).

\section{Tensions}

Protestant, including Evangelical, relationships to holy places, to material piety, and to localized religious practices have received considerable attention in theological, historical, and anthropological literature recently (Bielo 2016, Blanton 2015, Engelke 2007, 2010a, McDannell 1995, Meyer 2015, Morgan 2007, Kaell 2014, Keane 2007, 2009); several of these works have criticized earlier representations of Protestant Christianity that have too often described it as rejecting material forms of religion. While it becomes clear from these studies that Protestants, Evangelicals, and Pentecostals engage (and perhaps have always engaged) in a range of practices in which both material objects and particular sacred places fulfill central religious roles, many authors have also stressed how Evangelicals in particular tend to emphasize a God that is readily available anywhere. Matthew Engelke has called this aspect of Evangelicalism "the fantasy of immediacy", by which he means "a relation to the divine that is free from unnecessary and perhaps even counter-productive trappings" (Engelke 2010a, 2). In Engelke's view, such a "fantasy of immediacy" is motivated by a "concern with mediation and its material instantiations" (ibid.). A similar argument has been raised by Webb Keane who has suggested that Protestant intimacy with the divine is often created precisely through an ideological rejection of materiality and sociality (2007). How can these different aspects (the material and the anti-material, the locative and the utopian) in contemporary forms of Evangelical religion be squared, and how do they relate to the discursive production of Israel as a sacred space which was discussed above?

A first step would perhaps be to recognize that anxieties about materiality are very real in certain forms of Protestant Christianity while at the same time acknowledging that these anxieties do not necessarily prevent Protestants from engaging with materiality and locality. "Ideological rejection" (Keane 2007) does not necessarily lead to a complete avoidance of material religious practices. Thomas Tweed, in his ethnography of Methodist pilgrimage for instance, has balanced these two poles by locating Protestant suspicion of sacred places, not in Protestantism as such but rather in reformation polemics.

In this Protestant view, establishing shrines and promoting pilgrimages risks endorsing the Catholic sacramental worldview with its mistaken, 
even morally dangerous, collapse of the distinction between the sacred and the secular. To designate a site as sacred, and venerate persons or objects there, muddles Protestants' understanding of God's relation to the world. It distracts from the authentic sources of religious authority and power: sacred Scripture and religious experience.

TWEED 2000, 42

As Tweed's own ethnography testifies, however, this "Protestant view" does not prevent the United Methodists that he is studying from worshiping at the shrine that has been erected at the place where John Wesley first stepped onto American soil. Similarly, in his Hittin' the Prayer Bones Anderson Blanton has described "the way prayer, even within a historically iconoclastic Pentecostal tradition that overtly postulates no mediated grace and the immaterial nature of divine communication, subsists upon a material underbelly that actively organizes and inflects the way divine communication is experienced and understood by the charismatic faithful" (Blanton 2015, 3).

In what follows I discuss two aspects of the relationship between materiality and divine presence that emerge from the Evangelical volunteers' discursive construction of Israel as a sacred space: theological tensions concerning Israel's unique ability to mediate divine presence, and instances where the empirical reality of the place collides with its sacredness. These aspects can be summarized under what has been called "a problem of presence" (Engelke 2007, Keane 1997b, Orsi 2005), namely, how religious practitioners claim to construct a relationship with God through the investment of religious "authority and meaning in certain words, actions and objects" (Engelke 2007, 9, Keane 1997b, Orsi 2005). Engelke understands the problem of presence as the outcome of a "core paradox of Christian thought" $(2007,9)$ : the simultaneous presence and absence of God. It might be argued that this paradox is not a particularly Christian phenomenon and that similar tensions might be found within other religious traditions as well, but where "the problem" takes on its particular Christian shape is with the passing of the Christ-event $(2007,13)$. Drawing on the work of Paul Ricoeur (1998) and theologians John Milbank (1997) and David Tracy (1981), Engelke argues that Christianity is marked by two notions of "absolute difference" which in theological tradition are discussed in terms of the "creation" and the "fall". While both events can be seen in terms of a fundamental separation between God and creation, the second difference has been understood in much Christian theology as being "closed" by the Christ event. Nevertheless, after Jesus' tangible presence in the world the problem takes on a new (particularly Christian) form: 
How is God present? This is a central Christian question, to which the answer is Christ. And yet, with his passing, the answer becomes conditioned by an absence. Christ is the definite presence; what comes after him is only ever a mediated one.

ENGELKE 2007, 13

As Engelke points out, this question of the mediation of divine presence is the very locus of the church-in-history. It is a question over which battles have been fought, divisions have taken place, and new instantiations of Christianity have been formed. In Engelke's reading of the Reformation struggles, the Protestant emphasis on "Sola Scriptura" was a conflict of representation. What material objects, inner-worldly structures, and events can authentically be claimed to represent the divine? Protestants had an interest in limiting innerworldly representational artifacts and focusing on the Bible as the sole (or the main) material object with a legitimate claim. The Protestant solution to the fact that the Bible is a material object was to treat it as "[in]significant in its materiality" $(2007,21)$, thereby theologically differentiating it from other material objects (icons, holy sites etc.) that possessed some claim to authenticity in representing the divine. ${ }^{23}$ In Engelke's ethnography of the Friday Masowe Church in Zimbabwe, the problem of presence emerges out of these Christians' "simultaneous emphasis on the death of Jesus and the promise of a live and direct [i.e. unmediated] connection to God" $(2007,15)$, which make them reject the Bible as without value to their faith. In Hillary Kaell's study of American pilgrims to Israel "the problem", she writes, is primarily linked to the Christevent and biblical history (where the incarnation happened); among the volunteers, as noted above, it is primarily linked to the "biblical" present (where the restoration happens). ${ }^{24}$ If God is readily available anywhere how is it that he is

23 A theological contestation of particular relevance here is the one Engelke discusses under the rubrics of "liberal" and "conservative" Protestantism. While "liberal" traditions have viewed the Bible as a "guide" and emphasized "interpretation", conservative theologians saw the Bible not only as guide but also as "destination" and, instead of interpretation, emphasized "revelation". "In the most stringent of these faiths", Engelke writes, "the materiality of the Bible became presence of the divine-not representation, but presence; not sign, but actuality" $(2007,22)$. The most "stringent" conservatives then were the ones who limited the distance between sign and meaning so that they appeared as one and the same.

24 And I believe part of the difference in emphasis between Kaell's and my analysis is accountable by the differences in our respective field sites. Kaell studies American Evangelical and Catholic pilgrims to Israel, a much more religiously and ideologically diverse group than mine. Many of her informants presumably would not have seen 
uniquely accessible in Israel? If Israel is understood as having a unique ability to mediate divine presence, to what extent is this experienced as a conflict with Evangelical understandings of how relationships with God are properly constructed and maintained? Finally, when Israel does not function as expected, how does this influence its ability to serve as a mediator of divine presence?

\section{Another Problem of Presence}

The Protestant heritage that Tweed describes, and with it, the lurking threat of fetishism (Keane 1997a, 2007), are genuine concerns for some of the volunteers. To some extent these anxieties need to be placed in relation to the polemical discourses about the meanings attached to the State of Israel in various Christian contexts that were described in Chapter One. What is safe to say about Israel without being subjected to iconoclastic critique from other Christians?

In the beginning of this chapter it was argued that the phrase the "land of the Bible" among the volunteers does not only refer to Israel's history, but also to its "biblical" present. This investment of religious authority and meaning in contemporary Israel, in its socio-political, economic, and scientific developments, as well as in its cultural forms (Jewish music and dances, modern Hebrew, food customs, the social organization surrounding the Shabbat etc.), produces the State of Israel as a particularly potent sign. Not unlike the Bible, it becomes a signifier that to some extent — exactly to what degree remains contested — can be claimed as authentically representing God. However, explicitly arguing that Israel serves as a mediator of God might bring the volunteers into a theological conflict both with the more general utopian orientation in Evangelicalism and with the Protestant theological heritage. While liberal Protestantism is frequently engaged polemically in the discourses of the volunteers, however, some of them also seem concerned not to strive too far in terms of the mystification of Israel. Not all volunteers recognize these tensions; not everybody would care about them; the experience of Israel might have such an important role for them that other theological streams in their religious heritage are easily forgotten. Some do, however, quite often those higher in rank within the organizations, and quite often those with a theological education. In those cases, the role and importance of Israel is negotiated in relation to this heritage, and attempts to solve the tensions appear. In the discourse below, Tomas, an American volunteer involved in planning Evangelical tours to Israel, addresses these tensions in a discourse about the unique experience that Israel can provide to

any religious significance in Israel as a state but only in Israel as the historical land of the Bible. 
Christian travelers. For Tomas the solution lies in an emphasis on individual readiness to receive God.

I mean [someone] said, "Why read about prophecy when you can live it?"25 And obviously there's an element to this question that you will never be able to fully convey to someone, or open their eyes to it completely in the way as when you're here. ... And you yourself know that, I mean you've walked here ... You know, I can read about how to restore a car, you know, let's say you take a ' 67 Corvette. And I can read about, ok, this is how you can restore it, this is what it would look like if it's restored; but then to actually do that will give you satisfaction beyond description that you may not even be able to convey to someone who's never done that ... So I think there's a unique connection to this land for the believer [that] you can't get anywhere else. And I'm not just talking about praying or seeking God, because you can do that anywhere and God will, God you know, you can't hide from Him. And God will speak to you anywhere. But there's a unique connection. So when a Christian walks this land, experiences God with an open mind, open heart, ready to be, ready to receive. Because the soil itself isn't magical, you know. It's not like you can pick up the soil and it will—poof! — and it becomes a bunny rabbit. You know, it's not like we literally and physically worship the stones and the soil ... And so it's not mystical in that. ${ }^{26}$ But I think there is a deep connection to the heart of a Christian here and through that connection and the journey (because everybody's journey's different) but through that journey because God's speaking to you in a unique way, that if we are willing and able, transformation and change comes through that. And this goes back to the whole analogy of the car. You know, [the owners of the Corvette] didn't know how to fully describe it and convey it. I mean they could show pictures on a computer, they could point out this Scripture in the Bible, but there's a part that you just cannot convey unless you're here. And, that's I think the excitement [is] about, part of the excitement about coming here, part of the experience about coming here. But there has to be a destination. You know, we're not just coming here as an experience, like an emotional

25 "Don't just read about prophecy when you can be a part of it." As we saw in Chapter One, this slogan is used by the Bridges for Peace in newsletters, pamphlets, and promotional material and it hangs on a big banner in the headquarters in Jerusalem.

26 It should be noted that while the volunteers regularly refer to Israel as a "miracle", none would understand Israel as "magical", or "mystical" in the sense implied here. This reflects both cultural conventions about how divine agency is commonly described but also, I think, "the implied hierarchy of monotheism" that Shanafelt discusses $(2004,322)$. 
high as if it's some, like drug. You know, there is a destination which is really: am I cleaved unto God? Am I loving God with all my heart, soul and mind? Because it's all about God and not about Israel.

I have quoted this passage at length here because the discourse as a whole illustrates how Tomas oscillates between two different approaches to divine mediation-between discursively constructing Israel as a sacred space where God can be uniquely experienced and, at the same time, affirming the Evangelical "fantasy of immediacy" (Engelke 2010a, 2) — and how these two poles are negotiated. A similar negotiation was also visible in Adam's discourse, quoted above. Connected to this negotiation is an awareness of the threat of - and an attempt to shield the narrative construction of Israel as a sacred space from - theological fetishism.

The discourse is framed by the analogy of reconstructing a ' 67 Corvette that conveys the difference between abstract and experiential knowledge and at the same time illustrates why Israel is "unique": "restoration" is a concept applicable not only to the car wreck but also to Israel. Experiencing the restoration first hand, "being a part of prophecy" as it were, is the key to understanding Tomas' discourse about the transformative encounter with the land. However, "transformation and change", according to Tomas, comes through your personal readiness to receive God. You need to be ready to be blessed, ready to "experience the vibrancy of the Scripture", and you need to look at it "unbiasedly". On a conceptual level this implies that you need to be ready to move beyond your inherited "replacement theological" assumptions that hide the fact that Israel-of-today is a natural continuation of Israel-of-the-Bible, and you need to see the restoration without secular skepticism or modern bias. You need to be able to view Israel through the "Evangelical gaze". Being "ready to receive" requires a "suspension of disbelief": putting your skepticism aside and trusting in the conceptual links between the Scripture and the land that is conveyed to you in narrative performances. On the other hand however, Tomas repeatedly states that you can encounter God "anywhere" and that the soil of Israel is not innately magical: it cannot become a "bunny rabbit". Yet Israel has a unique mediating capacity to transmit divine presence; you receive God if you have a heart that is ready for it, but you do so through your encounter with Israel. This capacity does not come primarily through its ancient history, through being the place in which the Bible plays out-although that too is important; the mediating capacity comes through Israel as the land of the restoration. In the restoration of Israel, God entered history in a particularly tangible way, and as the restoration is a continuously ongoing project it is possible for people who are "ready to receive" to watch this restoration first hand. When biblical passages are linked to Jewish immigration, to Messianic forms of worship, to 
the development of agriculture or scientific discoveries, not only the land's social and cultural developments but also God's work become visible, and His presence comes to be intensely felt. It is through the implicit, and sometime explicit, links between the Bible and modern-day Israel that "transformation and change" happens. The soil is not magical, yet it seems that experiencing God is readily and particularly available in Israel. "It's all about God," Tomas says, but Israel is the vehicle through which (this specific) reception of God is made possible.

\section{Can Israel Fall Apart?}

Another question which concerns the problem of presence is whether the materiality of Israel presents a problem for its ability to serve as a mediator of divine presence. The "sacred space" discourse as it was outlined above often disseminates a highly idealized picture of Israel: it is the "land of the Bible", a place of miracle and wonder, a place identified with deep spiritual belonging and the presence of God. Yet something which is material is something which in its very nature can resist interpretation or symbolification. What happens when Israel does not conform to the standards imposed on it by the religious imagination? In Engelke's ethnography the fact that the Bible is a thing - that it can "fall apart" - is taken by his interlocutors as a sign of its functional limitations as a mediator. Something that can "fall apart" is material and as such takes away focus from what their Christianity is about: "a live and direct faith" unmediated by material objects (Engelke 2007, 7, 245). Can Israel too fall apart and, if so, how is that prospect handled by the volunteers?

As was discussed in Chapter Two, van der Hoeven frequently and explicitly criticized Israelis for not living up to their cosmological destiny, their selfdenial, and their failure to accept the role given to them by God. Similar critiques, if phrased in much more careful terms, are at times heard from the volunteers. Agnes, for instance, describes how she was shocked the first time she realized that there were Israelis demonstrating against the occupation of the West Bank.

But the first time I saw it, it just really made my heart sick and it still kind of does because here, you know, here are Jewish people who don't really understand that this land has been entrusted to them by God and they're willing to trade it for, for something, you know.

As for van der Hoeven, the problem for Agnes lies with those Israelis who do not accept the role that God has given them, who even "decline" the offer of Judea and Samaria and are willing to trade them for peace. Similar critiques 
are sometimes voiced by other volunteers, either in relation to leftist Israelis, or to the Ultra-Orthodox movement Neturei Karta. ${ }^{27}$

A related critique from volunteers concerns the treatment of Messianic Jews and congregations in Israel, and the general lack of a "spiritual restoration" of Israel: in other words, too few conversions to Messianic Judaism. While at times this is phrased in terms of freedom of religion, and discrimination against Messianic Jews is condemned on that basis, the eschatological models commonly upheld by the volunteers also play a role here in evaluating the state of Israeli society. "Spiritual restoration" is generally understood to follow upon the "physical restoration" of the Jewish people but, as one volunteer observes, not much movement in that direction is observable within Israel. In his case, although this is the only time I heard this during field work, it makes him question whether, and to what extent, Israel should really be considered a "fulfillment of prophecy". 28

As mentioned in Chapter One, a great deal of Christian Zionist activity in Jerusalem takes place within an "environmental bubble" (Feldman 2016) that to a certain extent shields the volunteers from aspects of Israeli society that do not fit neatly within their worldview. Many of them do not have any sustained relationships with Israeli non-Messianic Jews, and even fewer have any relationships with Palestinians. They spend most of their time with other evangelical volunteers at work, they often live in apartments organized by the ministries (which they share with other volunteers), they go to Messianic congregations during the weekends, and they generally travel little outside Jerusalem and Tel Aviv. There are certainly exceptions to all these general observations, some of which have been mentioned above, but when a volunteer socializes outside the environmental bubble it is usually because they have a personal wish to "learn more about Israel" or to make Israeli friends.

At one point during fieldwork I got the chance to explore the impact of the bubble, and to expose it to some external pressure. This happened mid-way through the third round of fieldwork when Adam, a young European volunteer, and I finally found some time to take a trip to Taybeh, a small Palestinian Christian town about twenty kilometers north of Jerusalem, and directly west of the large Israeli settlement Ofra. We had been talking about this trip for some time, and Adam had insisted on accompanying me there so that we

\footnotetext{
27 Neturei Karta is a fringe religious movement which opposes Zionism and calls for the dismantlement of the State of Israel. According to them, no Jewish state is legitimate prior to the coming of the Messiah. 
could experience the Palestinian territories, and of course, the family-owned brewery where they make the famous Taybeh beer. It was a fine day, and Adam and I spent our time in various Palestinian buses talking about the connections between the Bible and the land, between politics and religion, and about Jews, Palestinians, and the various identities present in the country. I also used the time to try out my early interpretations of the interviews on Adam and discuss the results with him. As noted above, it is very uncommon for Evangelical Christians on the Zionist side to visit the Palestinian territories or even the Palestinian areas of Jerusalem except on guided tours to the Old City or to Bethlehem or Nazareth. All through the journey, Adam took obvious pride in being adventurous and going off the beaten track; he laughed and made jokes about Christian Zionist fears of Palestinians and he eventually bought a little coffee mug in Taybeh which he said he would put on his desk in the Christian ministry where he worked: partly, I suspect, as a joke, partly as a provocation to his Evangelical colleagues at the office.

Adam is very clear about the biblical promises to the Jewish people, the eschatological expectations of Israel, and about the importance of the Bible in understanding the rights of the various groups inhabiting the land. Yet, compared to many of the other volunteers, he is also unusually critical of Christian Zionist beliefs and practices, and sometimes even of Israeli policies. Justice is an important value for him, and he is very attentive to, and disturbed by, talk or practices that he understands as racist or otherwise derogatory. This became evident as, on the way back to Jerusalem, we had to pass through Qalandiya, which is the location of the main checkpoint between Jerusalem and the northern part of the West Bank. As is common at the main checkpoints, we had to get off the Palestinian bus we had been riding, walk through the fenced lines up to passport control, answer the questions of the bored IDF soldiers, and get on a new bus on the southern side of the wall. I do not know if this was Adam's first up-close experience of the checkpoints or if the experience simply triggered thoughts that he had long held but once on the other side Adam erupted in criticism of the injustice of the situation, the abnormality of the separation wall, and how this situation must end.

To my mind, Adam's experience can be read as one example of the collision between the idealized narrative identity of Israel which the volunteers often express and the physical realities of the place; or, in less confrontational terms, where the two "Israels" that Patricia describes at the beginning of this chapter surface at the same time. Insofar as I could tell at the time, the experience does not make Adam question Israel's divinely mandated right to the land but it certainly makes him question the forms under which control of it is executed. He criticizes military control, the law of return (as unacceptable to Palestinians 
and an obstacle to peace), and he contemplates the terms under which a twostate solution could be possible and in line with the biblical commandments. Although it is not allowed to divide the land, he says, referencing Joel $3: 2,{ }^{29}$ Israel has already done so by building the wall, and besides, the land has been "divided" many times throughout its history.

Adam's critique is obviously different from the others mentioned above: in the previous cases the problem was that Israel, or Israelis, did not live up to the demands of eschatological narrative; in Adam's case Israel does not live up to his sense of justice. More importantly, while previous examples rely on the eschatological narrative to render judgment on Israel's moral status, Adam is explicitlynegotiating that narrative in an attempt to find ways in which to make it more "righteous". To my knowledge, Israel never completely "falls apart" for Adam because of his experience of the Qalandia checkpoint, but while he keeps reaffirming the biblical promises to Israel he also enters a situation of reinterpreting the meaning of these promises. At the very least, Adam's experience shows that while basing political support upon biblical promises sounds like a highly unyielding and inflexible ground for political beliefs, there is still room for negotiation if the conditions are right. "Absolutism" here, as in the case of biblical literalism that is discussed in the next chapter, better translates as "flexible absolutism" (Harding 2000, 275).

From a perspective of materiality all the examples above can be seen as instances where the material order resists, or fails to live up to, the demands placed on it by the religious imagination of the volunteers. However, none of these tensions seems to have the potential to overthrow the fundamental understanding of Israel as a sacred space, at least not insofar as these tensions have been experienced and expressed by the volunteers. I do think there are two rather straightforward explanations for this situation. First, as Jackie Feldman has observed in his study of Christian pilgrims to Israel, religious travelers to the land tend to have a confirmation bias. Pilgrims, like the volunteers, travel to the land more to be confirmed in their faith than to challenge it $(2016,90)$. In other words, they are more inclined to look for signs and listen to words that confirm their already existing understanding of the land, than to look for those that challenge it. This dynamic is probably further reinforced by the rather restricted social atmosphere of the organizations, and the limited exposure that most volunteers have to other ways of life within Israel. Second, when tensions

29 "I will gather all the nations and bring them down to the valley of Jehoshaphat, and I will enter into judgment with them there, on account of my people and my heritage Israel, because they have scattered them among the nations. They have divided my land." (my emphasis). 
arise, the volunteers are inclined to explain them as anomalies in the general structure rather than to take them as signifiers that their worldview is flawed. This is primarily achieved by relegating experiences that do not fit to the "Israel is a country like any other" discourse which was exemplified by Jennifer at the beginning of this chapter. In this discourse Israel is argued to be a normal country with similar problems to any other, and that it should be bound by the same moral standards as any other. As the sacred is constructed, so is the profane, but these two faces of Israel need to be kept apart in order not to muddle the understanding of Israel as a step in the redemptive process. By returning to the trope of "a country among others" when things do not fit, the vision of Israel as a unique sacred space can be kept pure, distanced from the phenomenological dirt of empirical experience. Certain aspects of Israeli history and social life are taken as representative of the divine while other aspects are deemed unworthy of this special status and thus relocated to the "country among others" discourse. As a result, the experience of Israel is split in two: one unique and one normal; one that mediates presence and one that does not.

\section{"To Live between the Tensions"}

Before closing this chapter I would like to return to the tension between sacred locality and the "fantasy of immediacy" that emerged in Tomas' discourse above. Although there have been Restorationist streams in Protestant thinking since the 17th century (Boyer 1992, Smith 2013), and although many other Protestant movements have recognized specific pieces of land and particular peoples as especially significant to God (British Israelism, Puritan immigrants in North America, Dutch Reformed theology in South Africa among others), mainstream Protestant thought has gravitated towards the universalist approaches and allegorical interpretations of the land promises in the Hebrew Bible. Against this background, Evangelical Zionist understandings of the land of Israel and its spiritual uniqueness emerge as something of a theological innovation, or at least, reformulation. As I have argued above, the novelty of their approach, and the tension in which it exists with some other Protestant streams of thought, is something which the volunteers are aware of, to various degrees. In an interview with David Parsons (media director of the ICEJ) he addresses this tension in a particularly explicit way when he criticizes Christian theologians and scholars who fail to see the enduring election of Israel in Scripture.

The problem today is this "fulfilment theology", that the land served a certain purpose up until Jesus, but that anything about the land going forward is just a metaphor that, you know, that Abraham, he didn't know it, but he actually was inheriting the cosmos and not just some little piece of real 
estate. And so they spiritualize the land under the New Testament. And they universalize everything ... you know, it's almost a type of Marcionism. ${ }^{30}$ But ... a lot of these Christian theologians, Christian scholars, whatever, they view the Old Testament as God revealing himself as a God of judgment and wrath. That the God who identified himself with Israel he just flew off the handle all the time and, was always getting angry and whatever, and that Jesus came along and revealed the God of love and mercy. Almost as if he's schizophrenic or he only wanted to reveal himself one way in the Old Testament and another in the New. And now everything is the universal love of God, there's no longer any preferred people, we're all children of God. And there's a certain truth to it. But Paul, his whole purpose in Romans 9 through 11 is-You know a Biblical paradox is an eternal truth presented in Scripture that has a parallel truth? And if you go and accept one truth to the exclusion of the other, that is the definition of a heresy: where you accept and propagate one paradoxical truth in Scripture to the exclusion of another. And, you know, a good example of this is predestination versus free choice. The Bible actually presents both. And the art of the Christian walk is to learn to walk between those two truths ... You know, I chose Jesus, but He chose me first; and, I may be predestined as a Son of God but, you know, I can also lose my faith. And what he [Paul] does in Romans 9 through 11 is he skirts with the exclusivity of election and predestination, but never to the point of excluding free choice and universal laws.

This discourse is essentially a defense for the unity of Scripture which is experienced as being threatened by "fulfillment theologians". This unity can only be preserved, in Parsons' understanding, by the embrace of paradoxical truths. The tensions inherent in the Christian Scriptures, and by implication in Christian faith, are solved by treating them as "parallel truths". Emphasizing one of them to the exclusion of the other is the very "definition of a heresy". The Christian walk is, rather, to learn to live with the tensions, to accept paradoxical truths and to remain faithful to the message of the Bible even in the face of paradox. Predestination versus free will is one of those paradoxes; the enduring election of Israel versus the universalism of the Christian message is another. ${ }^{31}$ In light

30 Marcion was a 2nd-century theologian who rejected the deity of the Hebrew Bible. His teachings were later denounced as heretical.

31 One might, of course, add other examples here: Engelke's "core paradox of Christian thought" - absence and presence; the dual natures of Christ (as fully divine and fully human); the divine-human authorship of the Bible etc. 
of Parsons' view, the oscillations in the volunteers' discourses between sacred space and quotidian Israel are not examples of indecisiveness but, instead, expressions of the tensions that define the Christian walk. Christian faith is inherently paradoxical, he seems to say; the "scandal of particularity"32 that emerges from Israel's enduring election is just one paradox among others that defines it.

After having described how "the land promise" is a central theme in the Bible, including the New Testament, Parsons comes to a conclusion when he sums up the implications of this theology, and, by implication, the religious meaning that is ascribed to Israel in these discourses.

This is the whole teaching of Scripture. And even though it's a specific land and it's a piece of real estate, you know. It's not about salvation and men's souls, that is correct. But the land promise has to do with how you view the nature and character of God. This whole question of what we're dealing with, your view on Israel, including the land promised to her, actually comes down to your view of the nature and character of God. And is He truly a covenant-keeping God who keeps his promises?

From Parson's perspective then, the restoration of Israel signifies a God that keeps his promises. The land of the Bible is a focus point that assembles the various strands in the narrative about the redemptive works of God and proves His loyalty and faithfulness. As we have seen, this narrative is not without contradictions; it is not without theological tensions; but the "art of the Christian walk" is embracing these tensions as paradoxical truths and accepting them as equally significant.

\section{Conclusions}

In this chapter I first described the volunteers' discourses about the land of Israel, and some of the ways in which Israel was constructed as a sacred space. I then discussed some of the tensions that can emerge in the encounter between these discourses and the concrete experience of place. If the problem of presence concerns how rightfully to construct a relationship to the divine given God's apparent absence after Christ, different Christian orientations have provided a wide variety of answers to this question. In Evangelical pro-Zionist thought, the land of Israel emerges as one type of answer; God is present 
everywhere but particularly so in Israel. Via Israel — through observation of its history and engagement with its culture, social and political life - it is possible to construct a relationship to God. Even if not entirely harmonious, the materiality of Israel does not present a problem for intimacy with God (Keane 2007) as much as it mediates it, even reinforces it. In To take Place Jonathan Z. Smith quotes the 17th-century philosopher John Selden who said:

The Jews had a peculiar way of consecrating things to God, which we [i.e. Protestant Christians] have not. Under the law, God, who was master of all, made [the] choice of a temple to worship in, where he was more especially present: just as the master of the house, who owns all the house, makes [the] choice of one chamber to lie in, which is called the master's chamber. But under the gospel there was no such thing.

SELDEN, quoted in SMITH 1987, xi

This "peculiar way of consecrating things to God" is, of course, represented in large sections of the Scriptures that Christianity has inherited from ancient Israelite and Jewish tradition, and it is represented in various instantiations of Protestantism. That John Selden found these interpretations of these texts "peculiar" and without religious significance post-Christum does not necessarily mean that other Protestant Christians will agree with him. The Evangelicals in Israel obviously do not. They spend their time in the "master's chamber", and even though the whole house belongs to Him, residing there is a particularly potent presence. 